\title{
Impact of Drought on Environmental, Agricultural and Socio-economic Status in Maharashtra State, India
}

\author{
Govind Katalakute ${ }^{1}$, Vasant Wagh ${ }^{2, *}$, Dipak Panaskar ${ }^{2}$, Shrikant Mukate ${ }^{2}$ \\ ${ }^{1}$ Finance and Accounts Department, Swami Ramanand Teerth Marathwada University, Dnyanteerth, Vishnupuri, Nanded (MS), India \\ ${ }^{2}$ School of Earth Sciences, Swami Ramanand Teerth Marathwada University, Dnyanteerth, Vishnupuri, Nanded (MS), India
}

Copyright $\mathrm{O} 2016$ by authors, all rights reserved. Authors agree that this article remains permanently open access under the terms of the Creative Commons Attribution License 4.0 International License

\begin{abstract}
The agriculture sector is the backbone of Indian economy, which contributes a major share of GDP of the country. Last few decades agriculture losses have grown due to irregularity in monsoon and change in climatic conditions over Indian sub-continent. Maharashtra state is developed and industrialized state in the country contributing highest GDP in the Indian economy. The present study assesses the effects of droughts on environmental, agricultural and socio-economic status during the year of 2011-2016 in Maharashtra state. The state occupies 50\% of the drought prone area. The state is experiencing deficit rainfall once in a 5 to 6 year, and severe drought conditions once in 8 to 9 years. In Maharashtra state, the \% to normal rainfall is gradually decreasing from the year 2011-2015. It shows large spatial variability in rainfall all over the Maharashtra state throughout the year confirms that Marathwada, Nashik, Amravati and Nagpur divisions received less rainfall in the year 2014 and 2015. Aurangabad division has marked as the lowest water availability in the reservoir of Maharashtra from the year $2012-2015$. The overall agricultural yield in Kharif and Rabi season is decreased to a considerable extent in the 2014- 15, which is near about $50 \%$ deficit in pulses, oilseeds and cotton as compared to the year 2013-14. Individuals and communities of Aurangabad, Amravati and Nagpur divisions (Cotton belt) are under pressure to cope with drought and its consequences. The farmer suicide cases were reported in the year 2015 (2016 cases) as compared to the year 2011 to 2014.
\end{abstract}

Keywords Rainfall, Drought, Economic Loss, Agricultural Yield, Administrative Division, Maharashtra

\section{Introduction}

The Meteorological drought defined as a situation, when, the seasonal rainfall over the area is less than $75 \%$ of its long-term average. A rainfall deficit between $26 \%$ and $50 \%$ of its average rainfall is classified as moderate, and more than $50 \%$ is classified as severe drought [1]. In India, $28 \%$ geographical area is vulnerable to moderate to severe type of drought [2]. Several parts of India faced severe drought conditions in 1918, 1972, 1987, 2002 and 2009 [3]. Drought is a prolonged phenomenon in which abnormally dry period extended and there is not enough water to fulfill the normal needs, resulting in widespread damage to Humans, crops, livestock and a reduced yields $[4,5,6,7]$

Maharashtra is well developed and industrialized state of India. It is the third largest state with geographical area occupying $307713 \mathrm{sq} \mathrm{km}$, holding 112.3 million populations [8]. The cultivable area is 2.25 lakh Sq $\mathrm{Km}$ and $17.6 \%$ is under forest [9]. Around, 55\% of the population depends on agriculture and related activities for their livelihood. The state has 36 districts which are divided into six administrative divisions, viz., Kokan (Mumbai), Pune, Nagpur, Amravati, Aurangabad and Nashik. Annual availability of water resources consists of $164 \mathrm{~km}^{3}$ of surface water and $20.5 \mathrm{~km}^{3}$ of subsurface water. In Maharashtra drought is one of the major natural disaster which leads to an enormous threat to the state economy and agricultural development. Therefore, the management of drought is a major concern and coping with this natural calamity needs extensive planning of water resources and agriculture. The severity of drought effects is mostly seen in rural areas as compared to the urban areas. The most drought vulnerable group includes farmers, labor and livestock. The direct effects of droughts are the reduction in agricultural yield and Industrial production [5].

The progression from agriculture drought to socio and economic drought causes famine situation resulting drought. At this stage, distress induces environmental degradation forces affected communities with acute food and water shortage. The situation also results in land degradation, fall in livestock population upsetting the energy cycle of the ecosystem [10].

The present study has been carried out considering these objectives, to assess the rainfall pattern, its spatial distribution and water availability in dams during 2011 - 
2015. The relationship of rainfall pattern, agricultural production, and farmer suicides in Maharashtra state during 2011-15 has been studied.

\section{Study Area}

Maharashtra state is situated at Western and Central part of India with geographical area 3, 07, 713 sq. km. and bounded by latitude $15^{\circ} 40^{\prime}$ and $22^{\circ} 00^{\prime} \mathrm{N}$ and longitude $72^{\circ}$ $30^{\prime}$ and $80^{\circ} 30^{\prime} \mathrm{E}$. The state has $720 \mathrm{~km}$ coastline along the Arabian Sea. The state has bordered with Karnataka, Goa, Madhya Pradesh, Gujrat and Telangana. Physiographically, the state is divided into three divisions, viz., Kokan (coastal area), Western Ghat (Sahyadri) and Deccan plateau. The state comes under tropical monsoon climate and receives rainfall from South -West monsoonal winds (June September). The rainfall varies according to physiographic divisions and uneven distribution is found in many regions. The kokan region receives heavy rainfall $(>2000 \mathrm{~mm})$, Deccan Plateau and Western Ghat receives medium rainfall (Avg. 600-1000 mm).The temperature varies from 12 to $45^{\circ} \mathrm{C}$ in winter and summer season respectively. The extreme summer is experienced in Vidarbha, Marathwada and Khandesh regions. The major agricultural area of the state is irrigated by main rivers like Godavari, Krishna, Koyana, Tapi, Narmada, Bhima, Wardha and Wainganga. The geological formations from part of Peninsular shield which is composed of ancient rocks in Precambrian, Proterozoic and Permocarboniferous periods. Deccan trap covers around $80 \%$ area of the state which is composed of Basalt, which has low permeability and porosity causes less water percolation leads to water scarcity and drought prone conditions prevailing in many parts of the state. The $90 \%$ economic minerals, viz., coal, iron, limestone, manganese, bauxite etc. found in Vidarbha and Kokan regions only.

\section{Methodology}

The rainfall and reservoir water storage assessment study have been carried out by using secondary data. The rainfall and reservoir water storage data provided by Water Resources Department (Jalsampada Vibhag), Govt. of Maharashtra has been considered for present study [11]. The division-wise rainfall data is represented in Figure 1. The graphical representation of division wise water availability of dams in different months is shown in Figure 2. The data of agricultural production of different crops during Kharif and Rabi season is obtained from Economic Survey of Maharashtra, published by Department of Economics and Statistics, Planning Department, Govt. of Maharashtra [12]. The data of farmer suicides is acquired from the Newspaper, Indian Express [13].

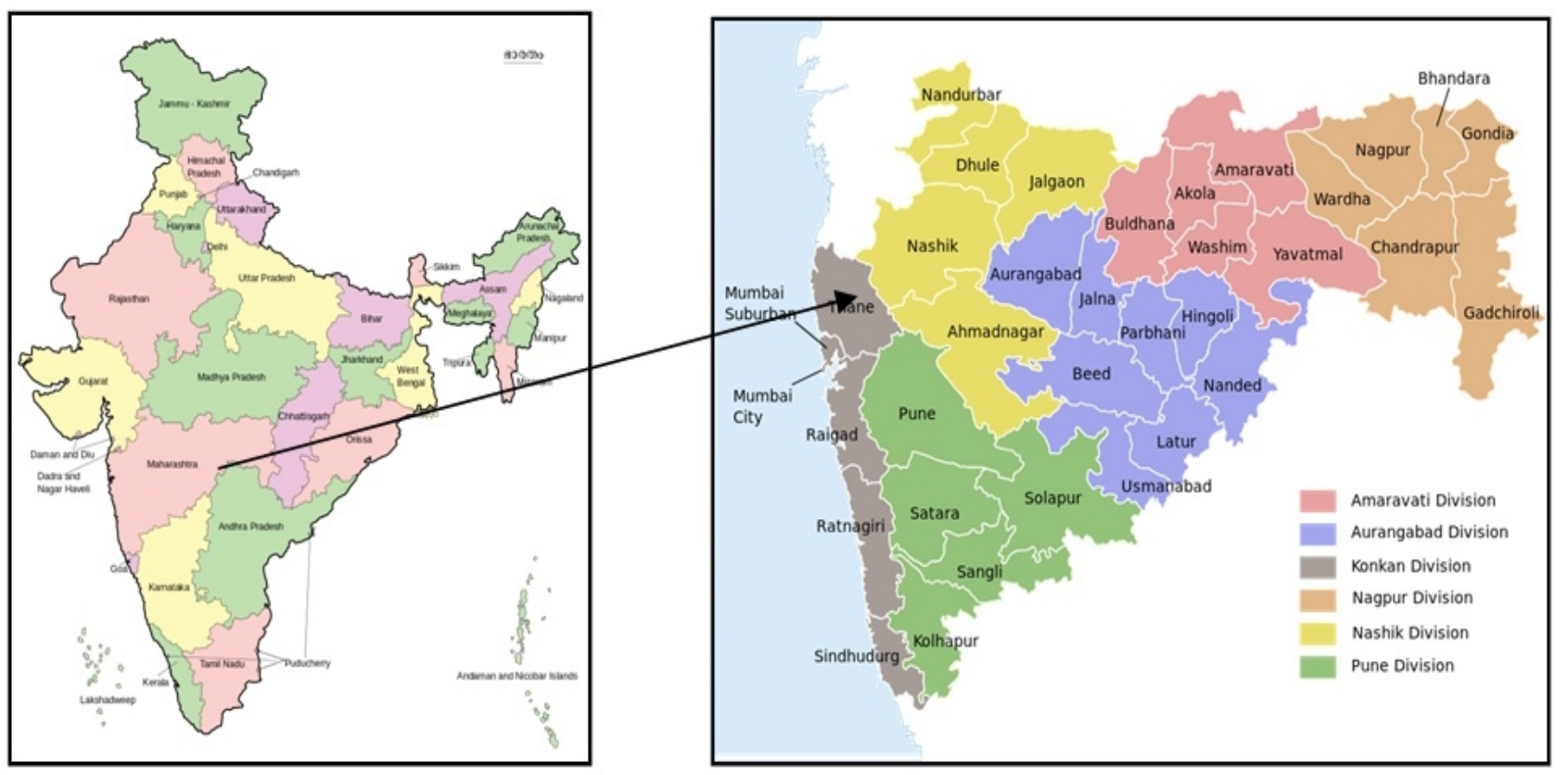

Figure 1. Study area with administrative divisions of Maharashtra 


\section{Results and Discussion}

\subsection{Deficit Rainfall in Maharashtra}

The data of $\%$ to normal rainfall (Table 1 and Figure 2) shows that there is a gradual decrease in rainfall every year except 2013. The spatial variation of rainfall (2011- 2015) in Maharashtra state is illustrated in Figure 3. It shows that the Marathwada, Nashik, Amravati and Nagpur divisions having deficit rainfall in the year 2014 and 2015. In the year 2015, there is very drastic change in rainfall; less than $65 \%$ of normal rainfall in Kokan, Pune, Nashik and Aurangabad division has been received. Amravati and Nagpur division were blessed with less than $80 \%$ rainfall. It is observed that in Nashik division there is a gradual decrease in amount rainfall from the year 2011 - 2015 except 2013 (107.36). However, in the year 2014 and 2015, the rainfall in Nashik division $(73.52 \%$ and $61.13 \%)$ has decreased to a considerable extent which leads to drought prone conditions in Ahmednagar, and Nashik districts.

In Pune division, it is clearly observed that the $\%$ to normal rainfall is below $100 \%$ from the year $2012-2015$, while in the year 2015 it dropped to $52.27 \%$ only. Due to such deficit rainfall, the water availability is decreased and area faced water scarcity problems basically in Solapur, Sangali and few tehsil of Satara district. The Aurangabad (Marathwada) division is under water stress conditions in last two years i.e. in the years 2014 and 2015. The rainfall is decreased by near about $50 \%$ to normal rainfall. Thus, it affected on Latur, Osmanabad, Beed, Jalana and Aurangabad district. These districts have been affected severe drought conditions. The Latur and Osmanabad districts were totally depending on a tanker for water. The Central Govt. of India made a special provision of Water Express railway to provide water to Latur City. The Amravati and Nagpur division of Vidarbha region experienced moderate rainfall in the years 2014 and $2015(71.47 \%, 71.47 \%$ and $68.7 \%$, $77.77 \%$ respectively). So, water scarcity observed in very few parts of these districts, viz. Akola, Buldhana, Chandrapur, Gondia and Bhandara.

\subsection{Division Wise Water Availability in Dams}

The graphical representation of division wise water availability during the year 2011 to 2015 is represented in Figure 4. It is concluded that due to deficit rainfall in Aurangabad division the water availability is very poor in all the seasons from the year 2012 to 2015. The water level marked to less than 20\% TMC in May of 2012, 2013 and 2015 , while in the year 2014 it is just up to the mark of $20 \%$ TMC. So, overall water availability is critical and causes drought prone conditions in Aurangabad division. Such less water availability affects the economy of the area, increases poverty and unemployment as well as the migration of the people from that area.

\section{$\%$ to Normal Rainfall}

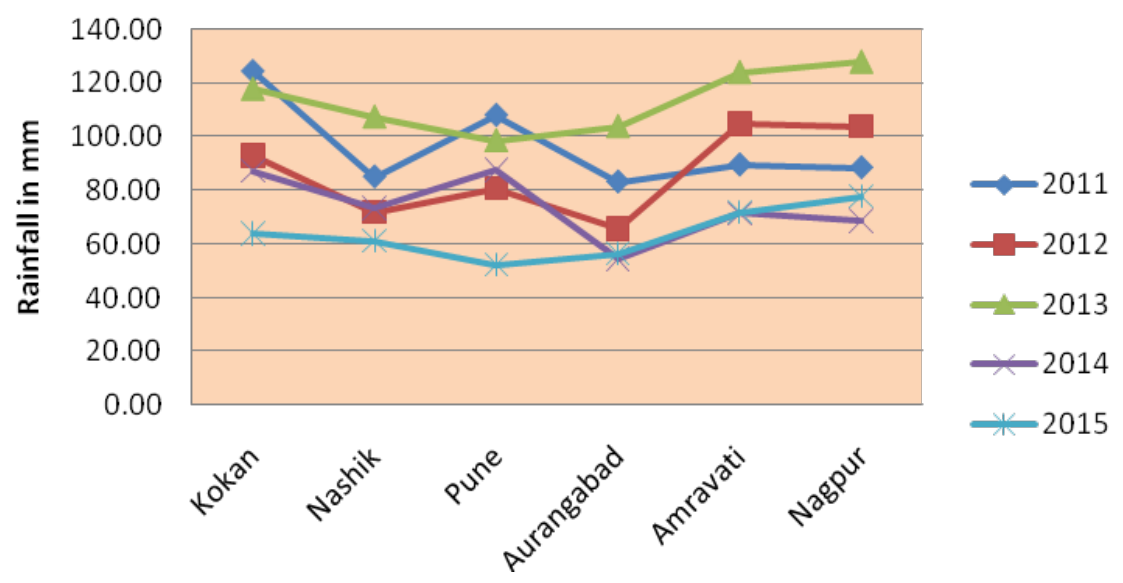

\# Excluding talukas in Mumbai City \& Mumbai Suburban districts

Figure 2. Graphical representation of division wise rainfall data [11]

Table 1. $\%$ to normal rainfall in Maharashtra state [14]

\begin{tabular}{|c|c|c|c|c|c|}
\hline \multirow{2}{*}{$\begin{array}{c}\text { Rainfall class } \\
\text { (percentage to Normal) }\end{array}$} & \multicolumn{5}{|c|}{ No. of Districts } \\
\cline { 2 - 6 } & 2011 & 2012 & 2013 & 2014 & 2015 \\
\hline Excess (120 and above) & 4 & 1 & 18 & 0 \\
\hline Normal (80-120) & 27 & 22 & 15 & 10 \\
\hline Deficit $(0-80)$ & 2 & 10 & 0 & 23 \\
\hline
\end{tabular}



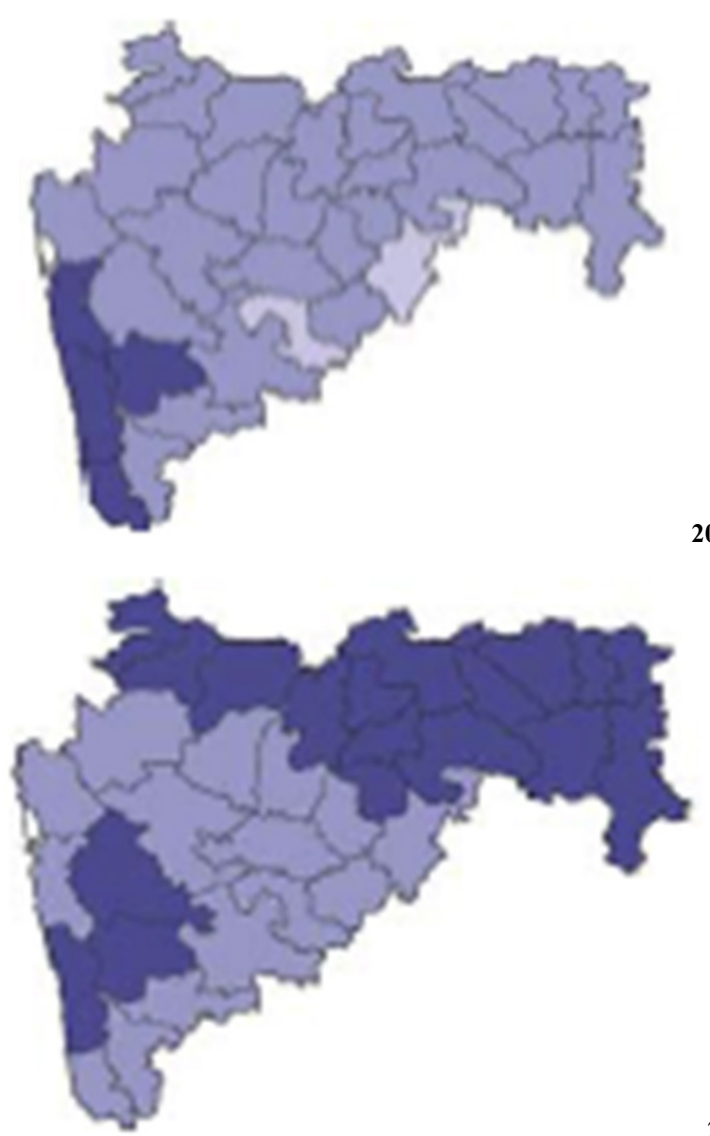

2013

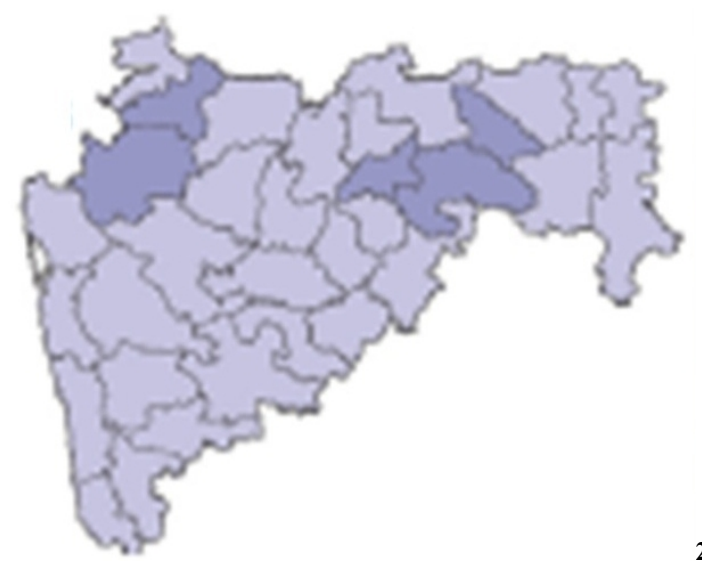

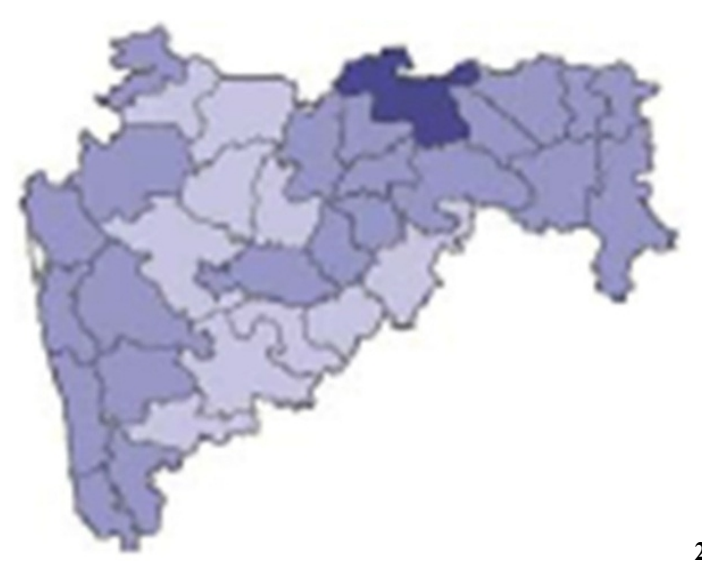

2012

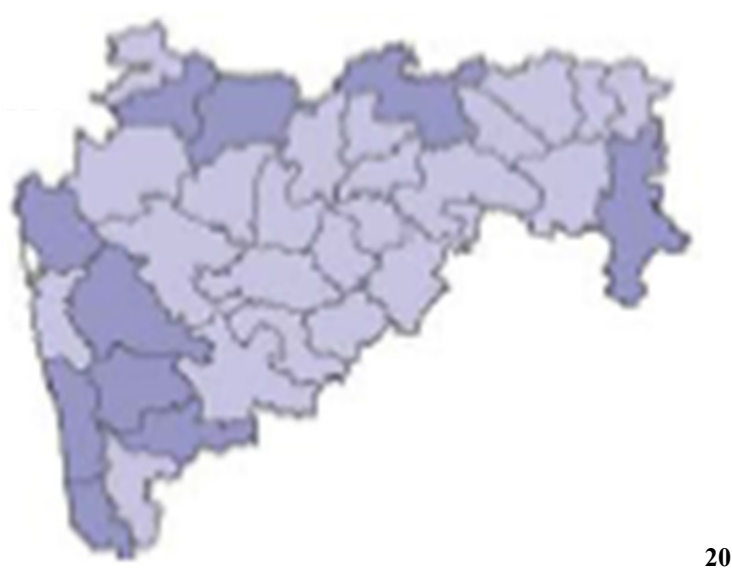

Legends
Excess 120 and More

Normal $80-120$

Deficient 0 - 80

Figure 4. Spatio-temporal variation of rainfall in Maharashtra

The kokan division receives a good amount of rainfall, so water availability is better than the other divisions. Amravati and Nagpur division also receives good rainfall and total availability of water is good for the month of September but due to extensive agricultural, industrial and urban activities causes the reduction of water up to $20 \%$ TMC in a month of May. Nashik division receives moderate rainfall; as a result, water storage in all types of dams is up to $80 \%$ TMC. This area is under good agricultural practices, hence water utilization rate is more, while in the month of May the water level goes down up to $18 \% \mathrm{TMC}$, in such situations the water is reserved only for drinking purposes.
Generally, Pune division has good water potential. In the month of May water availability is less than $40 \% \mathrm{TMC}$ in the years 2013, 2014 and 2015. The water utilization rate is more due to extensive domestic, agricultural and Industrial activities. The other dams include Bhatsa, Vaitarna, Tilari, Koyna, Erai, TATA's Dam and Dams under Mumbai Municipal Corporation. All the TATA's dams are located in Pune division and Mumbai Municipal Corporations dams are in Kokan division. These dams are located in rain-fed area of Maharashtra. The catchment area of dams receives good rainfall; hence, good water storage throughout the year. 


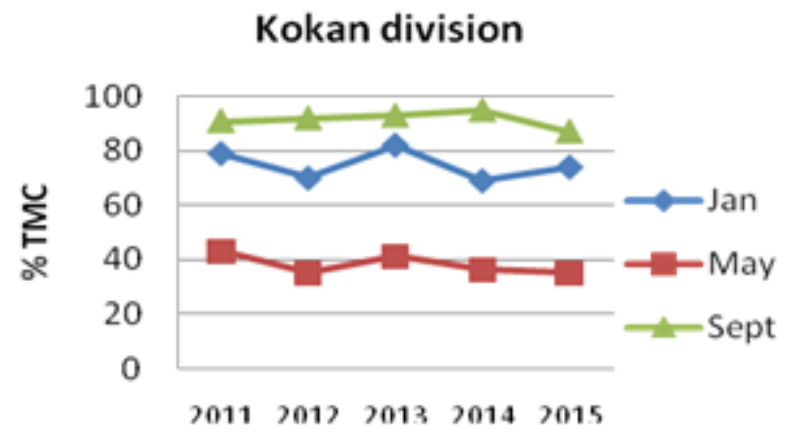

Nagpur Division

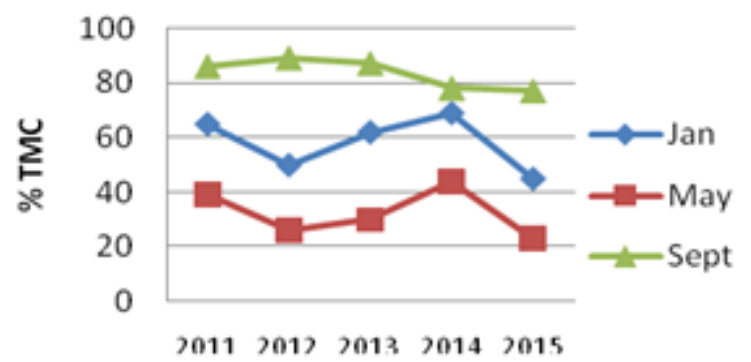

Nashik Division

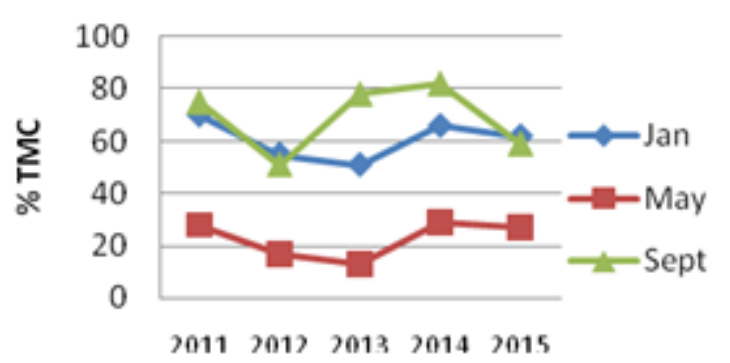

\section{Aurangabad Division}

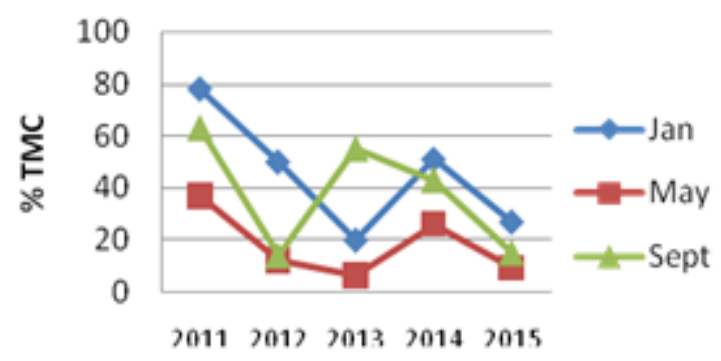

Amravati Division

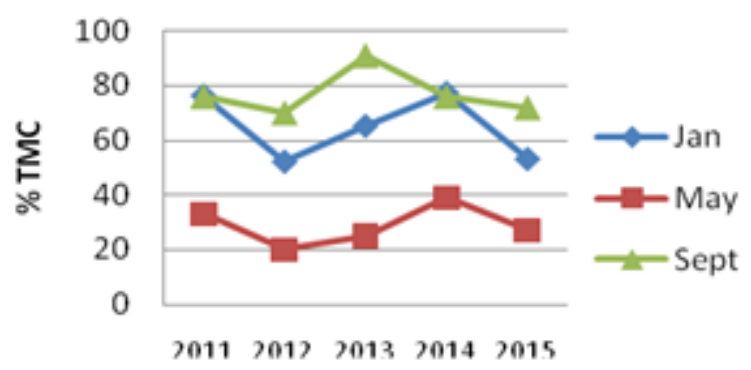

Pune Division

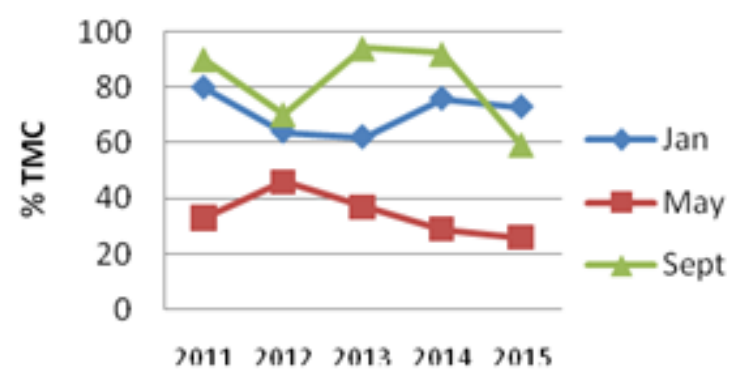

Other Dams

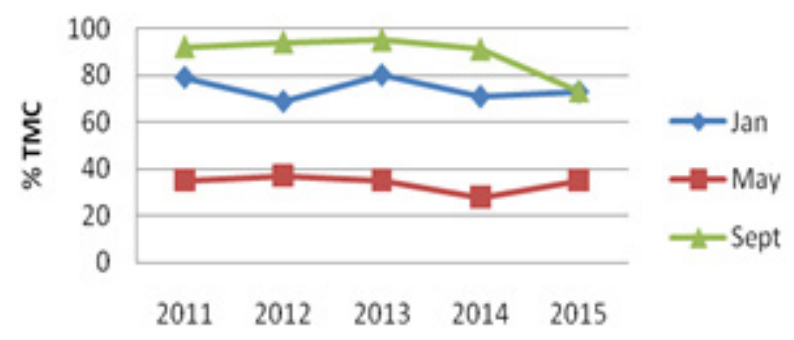

Figure 3. Season wise Water availability in dams of administrative divisions

\subsection{Agricultural Production}

The hydrological drought leads to the agricultural drought and then to socioeconomic drought. The rainfall deficit in the year 2013 and 2015 affected the overall agricultural yield of Maharashtra state (Figure 5). The agricultural yield has been increased in the year 2013 - 2014 due to the average rainfall. The yield is decreased to a considerable extent in the year 2014- 2015 and which is 50\% deficit in pulses, oilseeds and cotton than the previous year 2013 - 2014 and the major reason behind is deficit rainfall in 2014 and 2015 (Table 2).

\subsection{Farmers Suicide}

An agrarian crisis has precipitated a spate of suicides in Maharashtra. An important observation regarding farmer's suicide is that the number of cases has increased from 1495 (2011) to 2016 (2015) farmers per year except in 2013 
(1295). In 2013, the numbers of suicides were reduced to 1298 because of the good rainfall, the high agricultural yield and ultimately it saved the life. It suggests that the cotton belt of Aurangabad, Amravati and Nagpur division are more prone to committed suicide due to rising cost of cultivation, crop failure, indebtedness and bottlenecks in agricultural marketing [15].

Table 2. Production of major crops in Metric Tons (MT) [14]

\begin{tabular}{|c|c|c|c|c|}
\hline Crop type & $2011-12$ & $2012-13 * * *$ & $2013-14$ & $2014-15$ \\
\hline Cereals & 104.19 & 82.55 & 114.04 & 92.67 \\
\hline Pulses & 23.11 & 21.84 & 31.70 & 16.80 \\
\hline oilseeds & 44.92 & 51.86 & 48.12 & 22.78 \\
\hline Cotton* & 68.20 & 69.35 & 88.34 & 35.77 \\
\hline Sugarcane** & 894.56 & 596.89 & 769.01 & 915.38 \\
\hline
\end{tabular}

*Lakh bales $(170 \mathrm{Kg}$. each), **harvested area, ***tentative data

\section{Production of Major crops}

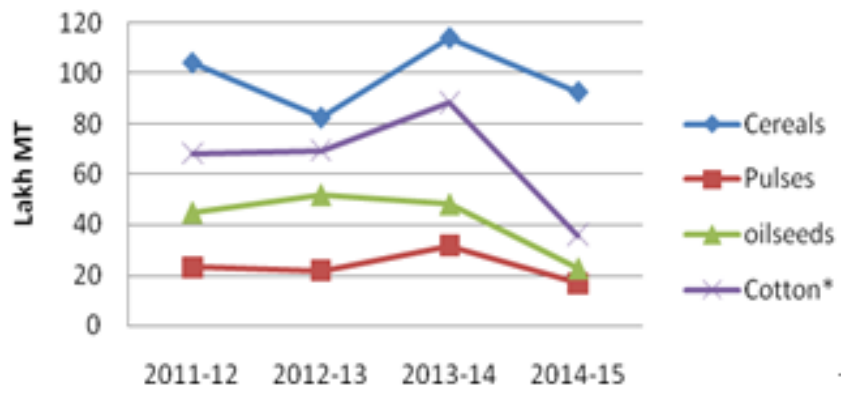

Figure 5. Production of major crops in Kharif and Rabi season

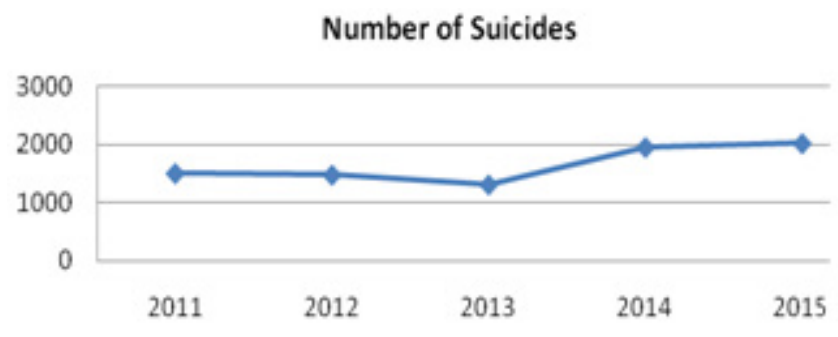

Figure 6. Number of suicides in Maharashtra state [13]

\subsection{Environmental Effects}

The continuous drought prone condition leads to groundwater depletion in many areas of the state. The people are harnessing water from $>600$ meters through bore wells, also simultaneously the frequency of bore wells increased. With this rapid rate of water exploration, in nearby future, our generation will pose the water scarcity. Long term severity of drought leads to desertification process. This process affects human societies exert on the dry and fragile ecosystem. At the extreme, it can increase malnutrition and death, economic spoil and absolute unsetting of societies. The overall all kinds of the ecosystem are imbalanced and its consequences will remain for long period.

\section{Conclusions and Recommendations}

The present study concludes that in the year 2014 and 2015 the rainfall decreased drastically in Pune and Aurangabad division. As a result of the availability of surface water deployed in dams due to water used for domestic, agricultural and industrial purposes. As the severity of drought increases it directly affects on the agricultural sector and economy of the state. The people from drought affected areas started migration towards urban areas of other parts for employment. Drought disrupts the agricultural production, and the equilibrium between supply and demand of agricultural products will be broken, ultimately increases inflation. The agricultural production of cereals, pulses and cotton in the year 2015 has been reduced to $50 \%$ to the previous year. The drought severely affected the cotton belt of Maharashtra where the highest number of farmer's suicidal cases has been reported in the year of 2015 . It is observed that in Aurangabad division the farmers are shifted to cash crop i.e. sugarcane, banana and turmeric like crops, which requires more water than the traditional crops of cereal and pulses.

The present study leads to certain recommendations which can recover the drought situation in Aurangabad, Amravati and Nagpur division. By adopting water-conservation techniques and proper crop planning the agricultural yield can be increased. The development of watershed will increase surface and groundwater resources. The drought management should be carried out through public participation and awareness to cope up with possible future droughts. Scientific improvement in breeding more drought-resistant animal and plants varieties will play a key role to balance the ecosystem. The water budgeting at all level is also very essential.

\section{Acknowledgements}

The Authors are very thankful to all Government and Private Agencies for making available the data. Authors are extremely thankful to anonymous reviewers for their constructive suggestions and comments.

\section{REFERENCES}

[1] India Meteorological Department, n.d. Frequently Asked Questions (FAQ). Accessed 19 November 2014 http://www.imd.gov.in/doc/wxfaq.pdf

[2] Samra J. S., Review and analysis of drought monitoring, declaration and impact management in India. IWMI Working Paper 84, Drought Series Paper 2, International Water Management Institute, Colombo, Sri Lanka, 2004.

[3] Indian Agricultural Statistics Research Institute, 2014. Agricultural Research Data Book 2014.http://iasri.res.in/agri data/14data/HOME_14.HTML. 
[4] Wilhite, Donald A., ed. Drought and water crises: science, technology, and management issues. CRC Press, 2005.

[5] Al-Riffai, Perrihan, et al., Droughts in Syria: an assessment of impacts and options for improving the resilience of the poor. Quarterly Journal of International Agriculture 2012, 51.1: 21.

[6] Gupta, Anil Kumar, et al., Bundelkhand Drought: Retrospective Analysis and Way Ahead. National Institute of Disaster Management, New Delhi 2014: 148.

[7] Lin, Yingzhi, Xiangzheng Deng, and Qin Jin., Economic effects of drought on agriculture in North China. International Journal of Disaster Risk Science 2013, 4.2: 59-67.

[8] Registrar General, India. Census of India 2011: provisional population totals-India data sheet. Office of the Registrar General Census Commissioner, India. Indian Census Bureau, 2011
[9] Patil A. K., Problems and Prospects of Agriculture in Drought Prone Area in Maharashtra. Unpublished report

[10] Goel, Sumer Lal., Disaster Administration and Management: Text and Case Studies. Deep and Deep Publications, 2007.

[11] http://maharain.gov.in/

[12] Economic Survey of Maharashtra, Department of Economics and Statistics, Planning Department, Govt. of Maharashtra.

[13] Indian Express, November 12, 2015

[14] Commissionerate of Agriculture, Govt. of Maharashtra, India.

[15] Mohanty, Bibhuti B. We are like the living dead': farmer suicides in Maharashtra, Western India. Journal of Peasant Studies 2005, 32.2: 243-276. 